Mészáros Zsolt

\title{
A 19. század végi magyar divatlapok és a nőmozgalmak: a Magyar Bazár (1873-1901)
}

Szem előtt tartva a nyomtatott sajtó kulturális, társadalmi, politikai, piaci összefüggéseivel számoló, tudományközi megközelítések tanulságait, a 19. század végi magyar divatlapok közvetítő szerepére kívánok rámutatni a hazai nőmozgalmak történetében, valamint hozzájárulásukra a nők szerveződéséhez, önállósodásához. Behatóbban a Wohl nővérek által 1873 és 1901 között szerkesztett Magyar Bazárt vizsgálom meg, más példákkal kiegészítve.

A médiakutatásokban már az 1960-as években megjelent, de az 1980as évektől megerősödő kultúratudományi szemléletnek köszönhetően került előtérbe a magánélet, a hétköznapok, a társadalmi és etnikai kisebbségek, a társadalmi és kulturális identitások, a marginális csoportok, a lokalitás, a centrum-periféria viszonya, a tömegkultúra, a közélet-politika-nyilvánosság, a szórakozás, a kulturális fogyasztás szerepe és jelentôsége (Császi 2008). A kultúrakutatások tudományközi nézőpontja dacára a történészek és a kommunikációval foglalkozók szorosabb együttműködésének igénye évtizedek óta szerepel a médiakutatások napirendjén: a McLuhan munkásságából kiinduló technológiai fókuszú kutatási hagyománytól való elmozdulást, a társadalmi összefüggések figyelembe vételét, a szakmai párbeszédet, a történeti megközelítést, a médiajelenségek múltja és jelene közötti különbözőségek és folyamatosságok feltárását szorgalmazzák (Nerone 2006, Curran 2008, Zelizer 2008, Conboy-Steel 2015).

Az utóbbi évtizedekben Magyarországon is jelentkeztek a különböző társtudományok felől helyzetértékelő, problémafelvető, jövôt vázoló módszertani írások, amelyek a hiányokból, feladatokból, igényekből kiindulva, és a nemzetközi szakirodalom friss szempontjainak beemelésével a hazai médiakutatások, azon belül a sajtótörténet új alapokra helyezése mellett érvelnek, arra emlékeztetve, hogy az akadémiai feldolgozás 1892-nél megállt. A korábban jellemző leíró, tartalmi ismertetések, formai bemutatások helyett javasolják a módszertan kiszélesítését, a makro- és mikroszintú vizsgálódásokat, a társadalomtörténet bevonását, az új források keresését, a periodizáció újragondolását, az előállítás-terjesztés-befogadás viszonyrendszerének komplex feltárását, a nemzetközi kontextusba való beillesztést, valamint olyan elhanyagolt témákra hívják fel a figyelmet, mint 
például a sajtöüzemek és -vállalkozások múködése, az újságírók professzionalizálódása, a sajtófogyasztás, a kép és a szöveg kapcsolata, a politikai és piaci összefüggések, vagy az olvasói szokások. Bár szerzőnként kiki máshová helyezi a hangsúlyt, de mindnyájan egyetértenek a mindmáig hiányzó alapkutatások szükségességében, a tudományközi szemléletben, a társadalom- és médiaelméleti belátások hasznosításában (Sipos 2003, Széchenyi 2004, Szajbély 2005, Gyáni 2006, Lipták 2011, Z. Karvalics 2014, Bajomi-Lázár 2015). Az általuk emlegetett sajtótörténeti hiányok közé sorolható a magyar női sajtó feldolgozásának elmaradása. A női sajtó képlékeny, viszonylagos fogalma alatt itt azokat a periodikákat értem, amelyek explicit módon pozícionálják olvasóikat „nőkként” (Beetham 1996, VIII).

\section{A nőknek szánt lapok megítélése a szakirodalomban}

A hazai sajtótörténeti kutatásokban elsősorban a nók médiareprezentációival, illetve a múlt századelő feminista periodikáival foglalkoztak, de a magyar női sajtóról átfogó, azt definiáló munkák nem születtek, leszámítva néhány tanulmányt, amelyek közül Nagydiósi Gézáné 1958-ban megjelent összefoglalója tekinthető mindmáig a legteljesebbnek a 19. századra vonatkozóan (illetve még lásd Kéri 2008, 26-32). Az utóbbi időben azonban örvendetes módon felélénkült a téma iránti érdeklődés. Ez a pozitív elmozdulás intézményi szinten is jelentkezik. A nők és a nyomtatott sajtó viszonyát tárgyaló friss kutatási fejleményekről adott képet a Bölcsészettudományi Kutatóközpont Irodalomtudományi Intézetének szervezésében 2019-ben megrendezett konferencia és az ahhoz kapcsolódó tanulmánykötet: „a tanácskozás és a kötet célja egyrészt a 19. századi írónők életpályájának, szövegeinek és publikációs stratégiáinak a korabeli sajtóközeggel összefüggésben való vizsgálata, másrészt a kifejezetten nőknek szánt időszaki kiadványok fókuszba helyezése volt.” (Török 2020, 8-9)

Nagydiósi Gézáné egyébként a lapcsoport meghatározására is kísérletet tesz, mivel pongyolának tartja a „női lap” kifejezést: olyan időszaki sajtótermékeket ért alatta, amelyek ,a nők különleges társadalmi, gazdasági és alkati helyzetéből folyó szükségleteket és igényeket kívánnak kielégíteni” $(1958,193)$. Jómagam Margaret Beetham konstruktivista felfogását követem, aki a kontextusból és a megszólításból indul ki: azt nevezi női magazinnak, amelyik explicit módon pozícionálja olvasóit „nőkként” (1996, VIII). Ugyanakkor az tapasztalható, hogy a „női sajtó” nehezen megragadható kategória, mivel olyan maszkfogalomként múködik, amely elfedi a különböző társadalmi, kereskedelmi és személyes előfeltevések, normák, jelentések, tapasztalatok és gyakorlatok bonyolult összjátékát. A 19. században az irodalomhoz (olvasmány), a múvészetekhez (múkedvelői tevékenység), az 
otthonhoz (háztartás, lakberendezés, kézimunka, család) és a testhez (öltözködés, szépségápolás, higiénia) kapcsolódó tartalmak avattak egy-egy lapot vagy rovatot „női”-vé, amelyek sok esetben a nemzeti kultúra ápolásának és terjesztésének felelősségével egészültek ki. E tartalmi gócpontok pedig azokat a feladatokat és szerepköröket jelölik, amiket a közép- és felsőosztálybeli nőknek tulajdonítottak az adott társadalomban.

A fenti témák nem mindig szerepeltek együtt, szabadon variálódtak a sajtókínálatban, és az egyes orgánumokon belül. A lapok fő- és alcímei, az előfizetési felhívások, a kortársak nyilatkozatai és egyéb források által kirajzolt töredékes kép alapján tájékozódhatunk arról, hogy egy adott sajtótermék milyen nemű közönséget céloz meg bevallottan vagy rejtetten. A magazin kevert müfajára többen utalnak, így a „női” magazin is közleményeiben (divattól, a valláson, a háztartáson, az irodalmon át a politikáig), kiállításában, a megjelenés gyakoriságában (heti, kétheti, havi) változatos képet mutat. Összehasonlítás kérdése, hogy mi mikor és miért minősült „,női” lapnak, függött az orgánum önpozícionálásától, olvasótáborától és tartalmától. Ez a három nem mindig fedte egymást a 19. század során, bár körvonalazható a női sajtó, mint lapcsoport, de határai nem rögzítettek; nézőponttól függően átrendeződnek. A magyar sajtóból veszek erre néhány példát. Az Új Idôke a család valamennyi tagját megszólító lapként határozta meg magát, így is tartja nyilván a sajtótörténet. Kádár Judit hivatkozva a lapban közölt hirdetésekre, szerkesztői üzenetekre és írásokra, meggyőzően érvel amellett, hogy főként női olvasókra számított (2002). A Fövárosi Lapok nevében vagy programjában sincs semmi, ami valamelyik nemet tüntetné ki, mégis a kortársak szemében női lapnak minősült. Erre utal a Borsszem Jankó 1884 és 1885 fordulóján publikált Magyar ujság olvasók címú karikatúra-sorozata, amely az egyes sajtótermékek közönségét az élclap alakjaival jelenítette meg, így a Fóvárosi Lapokét csupa női karakterrel: Juci szobalány, Cenci néni, Tinike, Lengenádfalvay Kotlik Zirzabella (Fabó 2007, 19). Benedek Elek a „kávénénikék lapjá”-nak nevezte a Fövárosi Lapokat, Rákosi Jenő is úgy emlékezett, hogy „egy napilap asszonyok számára” (1891, 646; 1926 I, 139). A Fövárosi Lapok hirdetésében viszont csak annyi áll, hogy összeállításai figyelembe veszik a női közönséget, de azt nem, hogy kizárólag nekik szólna: „Egyetlen társadalmi és szépirodalmi napilapunk, melynek előkelő, emelkedett és válogatott tartalma és iránya a múvelt hölgykörök finom izléséhez van mérve” (Fővárosi Lapok-hirdetés 1892). Velük szemben a Hölgyfutár, amely nevében, önmeghatározásában és sajtótörténeti besorolásában nőket megcélzó divatlap, ahogy azt több kutató is aláhúzta, a Bach-korszakban „sorok között” közvetített politikai információi révén túlmutatott e kategória határain. 
A beetham-i definíció alapján a divatlap beillesztése a női sajtóba egyértelműnek tűnik, mivel közleményeiben, hirdetéseiben, olvasómegszólításaiban nőket nevez meg, díszes fejlécében nőalak és/vagy nőinek tekintett jelvényekből - például zeneszerszámokból, kelmékből, virágokból összeállított csendélet, borítóján divatkép jelenik meg. Érdemes azonban emlékeztetni arra, hogy a divatlapok a női ruházat mellett foglalkoztak gyerekés időnként férfiviselettel is, olvasói között találunk férfiakat, illetve a 19. században léteztek kis számban és más felépítéssel ugyan, de kimondottan férfiöltözködésnek szentelt, nevükben is vállalt divatlapok a magyar piacon (Lukács 2016). Ezek elsősorban szabóipari közlönyökként a szakmának szóltak, de adtak divatképeket, -leírásokat és -tanácsokat. Az első hazai férfi divatmagazinnak, amely már polgári közönséggel számolt, a Mangold Béla Kolos által szerkesztett Férfi divat (1899-1908) tekinthetô.

A sajtó- és irodalomtörténészek a divatlap fejlödéstörténetének két szakaszát tüntetik ki figyelmükkel: a reformkort, illetve az 1850-es és 1860-as éveket (Mahotka 1934, Tamás Ernő 1939, Turák 1961, T. Erdélyi 1970, Miklóssy 1976, Tamás Anna 1970). Mindkét periódusban a divatlapot a korabeli társadalmi-politikai közegben, a nemzeti művelődés, azaz a magyar nyelv és irodalom terjesztése, magyar ipar és társasélet serkentése, a nemzeti viselet népszerúsítése fórumaként tárgyalják. Múködését irodalomszociológiai és művelődéstörténeti szempontból tartják jelentősnek, kiemelve a magyarul olvasók körének szélesítésében és a nemzeti eszmék közvetítésében játszott szerepét. Egyedül Pintér Györgyi vetette fel esetükben a női emancipáció felőli olvasat lehetőségét. Tanulmányában a társadalomtörténeti, médiatörténeti és gender szempontok bevonásával a reformkori divatlapok újraértékelésére hív, abból indult ki, hogy a divatlapok a női olvasókat megcélozva, nyilvánosságot teremtettek számukra, és ilyeténképpen „meghatározó szerepet vállaltak a nők művelődési jogainak kivívásában, az ezzel kapcsolatos szemléletváltás előkészítésében" (Pintér 2013, 42). A forradalmat követő két évtizedben a divatsajtó piaca gyors fejlődésnek indult, mindamellett, hogy a Világos utáni bonyolult engedélyeztetési procedúrák, az elkobzások és betiltások ezt a laptípust is érintették (Buzinkay-Kókay 2005, 115-119). A széles választékra világít rá a következő korabeli idézet:

Valaki azon eszmét penditette meg, s a tréfának komoly oldala is lehet, hogy jó volna fölöslegesen sok divatlapunkat egybetolni, mint hajdan Döbler tette bűvös poharaival. E fusiót következőleg lehetne eszközölni: A 'Nefelejts'-et egy 'Gombostü'-vel odatüzni a 'Virágcsokor'-ba, - a 'Virágcsokrot' bevinni a 'Családi Kör'-be s a 'Nővilág' keblére illeszteni, s midôn ily bájakkal fölöslegessé tenne minden 'Divatcsarnok'-ot, a 'Hölgyfutár' meghozná a hírt, hogy van egy átalános - 'Hölgy divatlap'! (Hölgyfutár 1862, 532) 
A magyar sajtó története szerint a forradalom utáni magyar divatlapokra az enciklopédikus családi lap típusa átalakító hatást gyakorolt (Miklóssy 1985, 417). Ebből adódóan a tanításnak és a mulattatásnak egyaránt eleget téve, a szépirodalom mellett tudománynépszerúsítő tartalmakat is közöltek. Mintaként az 1853-as alapítású, Lipcsében kiadott, itthon is széles körben olvasott Gartenlaube című hetilap szolgált, amely Közép-Európa műfajteremtő családi lapjának számított (Lipták 2002, 58-66). Az általa képviselt programba világnézeti semlegesség, nyelvi közérthetőség, képanyag, hazafias retorika, mértékletesség, ismeretterjesztés, szórakoztatás tartozott; jellege és rovatbeosztása (versek, folytatásos elbeszélések, tudománynépszerűsítő cikkek, útleírások, élet- és jellemrajzok, képmagyarázatok, levélposta, rejtvény) a magyar lapszerkesztésben is elterjedt.

A kortársak és szakértők egybehangzón úgy tartják, hogy a 19. századi divatlap pontos meghatározása helyett körülírásába lehet bocsátkozni. Legtöbbször a szépirodalommal fonódott össze, ahogy Áldor Imre szerkesztői búcsúja $A$ Divat 1867. szeptember 15-i számában reflektál a laptípus sajátosságaira: „Nincs nagyobb baj, mint a félszegség s a hazai divatlapok tengődése onnan származik, hogy megosztva erejüket se nem szépirodalmi, se nem divatlapok". A kutatók szintén a hibriditás felől értelmezik a divatlapot. T. Erdélyi szerint „nem szemle és nem családi lap, nem néplap és nem szépirodalmi folyóirat, nem magazin és nem napilap, de mindegyikből hoz valamit. A divatlap tehát az a kulturális sajtóorgánum, amely a kor- és közönségigényt szolgálta ki, s amely minden egyes rovatával egy-egy önálló lapot pótolt" (1970, 200). Buzinkay és Kókay szintén úgy látják, hogy egyszerre töltötte be a családi lap, a néplap és a szépirodalmi folyóirat szerepét $(2005,81)$. Pintér Györgyi pedig az időbeli változásokra hívja fel a figyelmet, hogy ,a divatlap a 19. század folyamán többször is átalakult - alkalmazkodva egy-egy korszak sajtórendszeréhez, közönségéhez - egyetlen szuperfogalom helyett inkább a divatlap változatairól beszélhetünk" (2013, 41).

A kiegyezést követően e laptípus elveszti maga iránt a magyar sajtótörténet-írók érdeklődését, akiknek egybehangzó véleménye szerint a 19. század második felében a divatlap elszakadt az irodalmi folyóirattól, és az öltözködés gyakorlati, technikai kérdései felé fordulva, korábbi aktualitása, népszerűsége fokozatosan lecsökkent, ritkán folyt vita hasábjaikon, és az is a lapon belül maradt, nézeteik szúk körben mozogtak, jelentőségük áttételesen a családi művelődésben mutatkozott (Dezsényi-Nemes 1954, Buzinkay 1985). Kitekintve a nemzetközi szakirodalomra, a divatlapot ott is sokáig ,félreeső helyként" értékelték, az utóbbi évtizedek média- és divatelméleti kutatásai fényében azonban kirajzolódni látszik sokrétú kapcsolódása a nyilvánossághoz, a nemzetépítéshez, a fogyasztáshoz és a modern kultúrához. Többen érvelnek amellett, hogy a divatsajtó kulturális normák, társadalmi 
nemi minták, fogyasztói attitűdök, nemzeti identitások alakításában aktívan közremúködött, ilyeténképpen a modern örve alatt zajló gazdasági, ideológiai, esztétikai folyamatok feszültségektôl sem mentes összjátékának par excellence fórumaként és cselekvőjeként fogták fel (Wilson 1985, Lipovetsky 1987, Breward-Evans 2005, Brevik-Zender 2015, Nelson Best 2017).

Visszatérve a hazai színtérre, valóban megfigyelhetjük, hogy a reformkori előzményekhez képest a divatanyag nagymértékben gazdagodott a 19. század második felében, ugyanakkor a szépirodalmi rész továbbra is megmaradt, hiszen annak rovatain keresztül lehetett kapcsolatot tartani az olvasóközönséggel. Tehát a szépirodalmi és a divatmelléklet egymást kiegészítette, egymást erősítette. Kétségkívül nagy volt a fluktuáció megszűntek, összeolvadtak, újak keletkeztek, gyakoriak a szerkesztő- és kiadóváltások - a lapcsoporton belül, de találunk olyan évtizedeken át sikeres példákat, mint a Családi Kör (1860-1880), a Magyar Bazár (1866-1904), a Budapesti Bazár (1860-1928) vagy a Divat Szalon (1888-1929). Elszigetelt múködésük helyett sokkal inkább azzal szembesülünk, hogy különböző mértékben, de továbbra is tevékenyen részt vettek politikai, társadalmi, kulturális mozgalmakban.

\section{A Magyar Bazár szerkesztőinek viszonya a nőmozgalmakhoz}

A feminista médiakutatások az úgynevezett második feminista hullámmal, az 1960-as években indultak meg, és a nemi elnyomás/kirekesztés formáit vették górcső alá (Carter-Steiner 2004, 11-35). Ennek a máig ható értelmezői hagyománynak képviselôi a férfiuralom és a piacgazdaság összefüggéseire mutatnak rá kritikai módon, és a női magazinokat gyakran a szórakoztatás forrásaiként, az egyenlőtlenség és alávetettség újratermelőiként azonosítják, amelyek olvasóikat a nôiség kultuszán keresztül illesztik a társadalomba (Beauvoir 1969 [1949], Friedan 1963, Ferguson 1983, Wolf 1999 [1990]). Az 1990-es évektől megélénkülő interdiszciplináris kutatások megtartva a kritikai szempontokat, ám módosítva a korábbi súlypontokon, a nők aktív szerepének, sajtótevékenységének és -fogyasztásának feldolgozására törekednek. A média- és kultúrakutatások ötvözésével a nőtörténet új perspektíváit nyitják meg (Ballaster et al. 1991, Beetham 1996). Ezek a feminista megközelítések, amelyek engem is ösztönöztek a Magyar Baz̧ár vizsgálatánál, a női lapok összetettségével számolnak, hogy heterogenitásukból adódóan nemcsak egy nőképet közvetítenek, hanem egyidejűleg több női szubjektumhoz szólnak. A történeti szemlélet mellett érvelnek, miszerint a nôiség konstrukciója tér és idő függvénye, amelyet más tényezők - például életkor, vallás, osztály, etnicitás - is befolyásolnak. Nem feledkeztek el arról, hogy a női lapok profitorientált vállalkozások lévén, 
valamint heterogenitásukból adódóan ellentmondásokat hordoztak, és nem képviselték az összes nő érdekeit, ugyanakkor kommunikációt teremtettek olvasóik között, a mindennapi és a társadalmi élet kihívásaival foglalkoztak, és azok nyilvános megvitatására adtak lehetőséget. Arra is felhívják a figyelmet, hogy nemcsak egyirányú befolyásoló hatás tételezhető a lap-olvasó viszonyban, hanem kölcsönös és dinamikus. A 19. század végi divatlapok esetében, az előfizetôk aktívan részt vettek az adott lapszámok anyagának összeállításában, akár a külön nekik fenntartott rovatok, akár beküldött véleménycikkeik, szépirodalmi vagy ismeretterjesztő írásaik révén, továbbá a divatlapok egyletek hírleveleiként, illetve nyílt rovataikon keresztül a kapcsolatteremtés, a szerveződés és együttmúködés különféle formáit elősegítve, múködtették olvasóik számára a közösség és a nyilvánosság kereteit (Mészáros 2017).

Arra is találunk példát, amikor a divatlap lehetőséget kínál hasábjain a társadalmi nemhez kapcsolódó szerepek, minták, elvárások megvitatására vagy éppen felülírására. A Magyar Bąár 1896. december elején „Egy megkeseritett hajadon" álnevú, harminckét éves előfizetőjének levelét tette közzé, akit mélyen bántott, hogy már vénlányként kezdtek el róla beszélni környezetében, miközben nem tartotta magát „sutba valónak”. Arra szólította fel a szerkesztőséget, hogy közöljék a levelét, mert kikérné az olvasók véleményét arról, hogy mikor tekintse magát egy hajadon vénlánynak? A válaszolók megosztották élettapasztalataikat, véleményüket, tanácsaikat, és az a konszenzus alakult ki közöttük, hogy a „,vénlányság” nem a korral vagy a státusszal függ össze, hanem a kedéllyel és a gondolkodásmóddal (Egy megkeseritett hajadon 1896). Hentaller Elma $A$ legújabb nöalakok címú cikke pedig arra hoz példát, amikor egy divatlap emancipált nőtípust állít pozitív mintaként a nyilvánosság elé, nevezetesen a gimnazista lányt és a női egyetemi hallgatót. A szerző a nemek közötti egyenrangú viszonyt, a nők anyagi helyzetének javulását várja megjelenésüktől, illetve olyan új női nemzedék előhírnökeinek tekinti őket, akik dolgoznak, akik meg tudnak élni a saját eszük után, és akik egy újfajta, független nöiséget képviselnek: „az önállóság becsületérzést, önérzetet, udvarias előzékenységet fejleszt benne, a mi eddigelé felesleges tulajdonságnak látszott a házi bálványként védett és oltalmazott nő számára" (Hentaller 1896, 173).

A Magyar Baðárt szerkesztő, középosztálybeli Wohl Janka és Stefánia számára a sajtó megélhetést jelentett, továbbá hatékony eszközt eszméik terjesztésére. Saját élethelyzetükből, tapasztalataikból merítve pályájukat végigkísérte a nőmozgalmak iránti elköteleződés, ha nem is voltak felforgatók, de azok sorába illeszkedtek, akik tevékenységükkel tágították a határokat. Személyes példaképük az anyai barátnő, Brunszvik Teréz volt, akinél visszaemlékezéseik szerint gyerekkorukban sokat tartózkodtak: foglalkozott 
velük, tanítgatta őket, például a kagylógyűjteménye segítségével. Magatartásban, látásmódban, jótékonyságban, munkában igazodási pontot jelentett a nővéreknek: „Bár minél több női lélek választaná azt vezérül s haladna ama fényes nyomokon, melyet Brunszwick Teréz életpályája jelöl." (Wohl Stefánia 1871, 177). A nők függetlenné válását mindketten történelmi szükségszerűségként, a 19. század meghatározó társadalmi és politikai folyamataként fogták fel, ahogy Wohl Janka kiemelte: „A tér és idő fogalmának megmásitása mellett a nő állásának teljes átalakulása tekinthető a tizenkilenczedik század második felének legjelentősebb vonásaként.” (1897a, 94) Húga pedig történeti kontextusba illesztve, különböző nemzeti függetlenségi küzdelmekkel hozta párhuzamba:

Fényes kardjának csattanására tán, mely a tövisbokrokat útjáról eltávolitá, sohajtott fel néhányszor a lányka mintegy sejtve, hogy szabaditásának órája közeledik, s e csattanásra a - és az ifju első csókjára Franciaország földe egy régi dynastia vérét itta, Washington lerázatta Amerikával az idegen igát, Németország ifjai véreztek el Lipcse mellett, s a nők - emberek lettek (Wohl Stefánia 1866, 257).

Ugyanakkor a politikai értelemben vett emancipációval óvatosan bántak, de ezzel nem álltak egyedül, mivel a hazai nőkérdéssel foglalkozók körében általánosan az a nézet uralkodott a 19. század folyamán, hogy őrizkedni kell minden „túlzástól”, amely alatt elsősorban az egyenjogúság követelését értették (Müller 2006, Sárai Szabó 2014). A Wohl nôvérek erőfeszítéseiket a természetesnek vett „női” tevékenységi körök és az új kihívások összeegyeztetésére fordították, mint, ahogy olvashatjuk a Magyar Bazár programjában az 1893-as évfolyam első számának címlapján: „Nem hirdetünk emanczipátiót, de melegen pártoljuk a szellemet és a testet edző nemes sportokat, - nem követelünk jogegyenlöséget, hanem munkára serkentünk mindenkit: dolgozzék ki-ki hajlama és tehetsége szerint”. A szellemi és anyagi önállósodásban látták azt a lehetőséget, hogy a nők lépést tartva a társadalmi, gazdasági, kulturális változásokkal, megfeleljenek családi szerepeiknek, illetve, hogy egyedülállókként teljes és hasznos tagjaivá váljanak a szûkebb és tágabb közösségnek. Megkérdőjelezték a házi és családi kötelességek, a magántér kizárólagosságát, és a nők szerepvállalásának, kiteljesedésének más területeire mutattak, mindemellett pedig reflektáltak a tevékenységeiket elöíró módon korlátozó normák megalkotottságára, mint, ahogy Wohl Janka fogalmazott cikkében, reagálva arra, hogy Deák Ferenc támogatása dacára, neme miatt elutasították Illésy Györgyné Ember Karolina folyamodványát a képviselőházi gyorsírói állásra: „,[a női munkavállalás terén] a körülmények zsarnok követelményei fogják legázolni az akadályokat, melyeket folyton elébe görditenek a szokások, a hagyományos elvek - és a 
férfiak." (Wohl Janka 1871, 18) Ugyanakkor azt is fontos hozzátenni, hogy a dolgozó és alkotó nőt nem kortárs jelenségnek tartották, hanem rávilágítottak történetiségére. Erre nyújt példát Wohl Janka $A$, „régi jó idôke” kiváló bölgyei címú háromrészes, a Fövárosi Lapok hasábjain közölt cikksorozata. A múlt híres nőalakjainak portrészerū bemutatása elterjedtnek számított a kor sajtójában, Wohl Janka esszéje abban más, hogy a tudós és a múvész nőket nem kivételekként értelmezi:

Azonban a világért se várja tőlem, hogy rendszeresen vagy kimeritőleg bánjak el tárgyammal. Kötetekre terjedne levelem, ha valamennyi nőt föl akarnék említeni, kik nemcsak szerencsésen múködtek a tudományok terén, de egyúttal életök fentartásáról is gondoskodtak s koruknak, századuknak díszei és büszkeségei lettek (Wohl Janka 1875, 438)

Maga a cím is ironikus még pedig a szöveg elején megidézett férfi vitapartner véleményére utalva, aki szerint a „régi jó idők”-ben nem létezett emancipáció, és a nők háziasan, szerény igénytelenségben töltötték mindennapjaikat a családi körön belül. Wohl Janka ezzel a közvélekedést tükröző állitással száll vitába írásában, és konkrét életművek révén a nők folyamatos szellemi hozzájárulását hangsúlyozza a kultúrához, a művészetekhez, a tudományokhoz: „... régmúlt idők fátyolát lebbentem csak fel imitt-amott, bizonyítva azt, hogy a női szellem mindenkor lépést tartott a haladással; hogy a női léleknek sokkal nagyobb része van a szellemi fejlődés csöndes munkájában, mint azt hinni lehetne..." (Wohl Janka 1875, 446) Lendületes argumentációja egyrészt cáfolja, hogy a nôk pótlék gyanánt fordultak és fordulnak a szellemi múködés felé (mert nem szépek, vagy nem boldogok, vagy nincs senkijük), másrészt pedig azt, hogy a nöiségtól idegen volna a ssenialitás (itt gondolhatunk a kor értelmiségi diskurzusaiban visszatérő fordulatra, miszerint nincs női Shakespeare, Michelangelo stb.); más szóval kikezdte a zsenialitás 19. századi fogalmának maszkulin konstrukcióját (Acsády 1996).

Már az első, 1870 és 1872 között általuk szerkesztett lapban, $A$ Divatban körvonalazódott az a szándék, hogy fórumot teremtsenek a nőket érintő társadalmi és kulturális kérdéseknek, ahogy Wohl Janka írta az egyik felkért munkatársnak, Szilágyi Sándornak 1870. november 3-án: „e lapot a lehetö leglelkiismeretesebben akarjuk kezelni, hogy idövel az europai szinvonalra jusson s megfeleljen a mindinkább nagyobb tért foglaló női kérdésnek.” (OSzK Kézirattár, Levelestár, Fond IX/725.) Ezt az irányt folytatták következő, 1872 őszén önálló vállalkozásként indított lapjukban, $A$ Nők Munkaköreben, amelynek szerkesztői beköszöntőjében a női hivatás reformját, mint égetô társadalmi probléma megoldását sürgették, és ennek kapcsán a nevelés, a munka és a jótékonyság hármasát nevezték meg lapjuk 
programjának (Wohl Stefánia 1872). A Nók Munkaköre figyelemmel kísérte mind a hazai, mind a nemzetközi nőmozgalmak fejleményeit, és hírt adott olyan törekvésekről is, amelyek bevallottan távol álltak a szerkesztôktől, például ismertették Szerényi Endre $A$ nöi emancipatio címú, politikai jogokat támogató művét a mutatványszámban. Továbbá a lap időnként átvett és kivonatolt témába vágó esszéket, írásokat az angolszász sajtóból (például Saturday Review, Westminster Review), Sámi Lajos pedig nagy gondolkodóként mutatta be az olvasóknak a nők társadalmi elnyomása ellen fellépő John Stuart Millt. Bátorságra vall, hogy a Wohl nővérek saját vállalkozásban olyan lapot adtak ki, amely mind címében, mind hangvételében, mind tartalmában eltért a korabeli, nőknek szánt periodikáktól. Erre világít rá az első számban megjelenő Ballagi Mór cikke, amely D. F. Strauss teológus Der alte und der neue Glaube címủ könyvét recenzálta. A bevezetőben arról töprengett a szerző, hogy hogyan ismertessen vallástudományi munkát nőknek, akik olvasták ugyan Homéroszt, Dantét, Shakespeare-t, Goethét, „de melyik nő merné bevallani, hogy ő tanulmányozta Kantot, olvasta Schellinget vagy Hegelt?” (Ballagi 1873, 1) A célközönségnek tulajdonított filozófiai ismeretek hiányosságát Ballagi úgy próbálta áthidalni, hogy a művel folytatott párbeszédet. Az Ország-Világ névtelenségbe burkolózó munkatársa $A$ Nôke Munkakörét olyan „szépirodalmi női folyóirat”-nak nevezte, amely „ebben a nemben úttörő volt” (Ország-Világ 1894). Valóban úttörő orgánumnak tekinthetô, de nem elốzmény nélkülinek, hiszen a Kánya Emília által szerkesztett Családi Kör akkor már évek óta kiállt a nők társadalmi szerepvállalása, munkavállalása és irodalmi múködése mellett (Bozsoki 2018). Továbbá érdemes utalni Báró Egloffstein Amália 1871-ben megalapított, rövidéletú Nók Lapjára, amely a korabeli sajtóban a legmarkánsabban és a legelőremutatóbban képviselte a nőmozgalmi törekvéseket: támogatta a női orvosok képzését, egyesülésre buzdította az országos nőegyleteket, felkarolta a nők közép- és felsőoktatásának eszméjét.

A Wohl nővérek és az országos jelentőségű Athenaeum Kiadóvállalat közös megegyezéseként $A$ Nók Munkaköre 1873 augusztusában egyesült a Magyar Bazár címú divatlappal. Az ennek nyomán létrejövő Magyar Bazár mint a Nők Munkaköre címú divatlap szerkesztését Janka vitte élete végéig, 1901 -ig, munkáját Stefánia segítette 1889-ben bekövetkező haláláig. Nagydiósi Gézáné szerint $A$ Nök Munkaköre jelentősebbé vált volna, ha nem olvad bele a Magyar Bazánba (220). Bár a fúzió során létrejött divatlap hozta mindazt, amit múfajától elvártak az előfizetők, nem csupán öltözködési tanácsokat, mûkedvelői, kultúrafogyasztói magatartásmintákat, hanem az egzisztenciateremtéssel, valamint a szellemi térnyeréssel kapcsolatos lehetőségeket és példákat is közvetített immár egy szélesebb női olvasótábor 
felé. A Magyar Bazár 1892. október 16-i szám borítékán közölt előfizetési felhívás így foglalta össze a lap célkitűzéseit:

...nem csupán a gyakorlati téren igyekszik tanáccsal és utasitással szolgálni, hanem divatlap és szépirodalmi lap létére, figyelemmel kiséri a szellemi élet és nő-kérdés minden lényeges mozzanatát és a női hivatás csaknem minden ágában, komoly és számot tévő módon segiti elô az önképzést.

A Magyar Bazár, bár hasábjain - összhangban a szerkesztők nézetével és magával a laptípussal - a választójogi mozgalom ritkán kapott teret, és összességében mérsékelt hangot ütött meg, de az emancipáció több szintjéhez kapcsolódva, teret adott a nőket érintő oktatás, tudomány, életmód, munkaképesítés és -vállalás felvetéseinek, problémáinak, megoldási alternatíváinak, így a házi- és nőipari mozgalomnak, a sportolásnak, a gimnáziumi és az egyetemi továbbtanulásnak. Lapjuk a hazai nőmozgalmak nagy alakjai (Brunszvik Teréz, Veres Pálné, Zirzen Janka) előtt visszaemlékezésekben, nekrológokban tisztelegett; a Magyar Bazár ezen cikkeiből kirajzolódó felfogás szerint a hazai nőemancipáció folyamatos építkezés eredménye.

\section{Önállóságra nevelés a Magyar Bazárban}

A Wohl nővérek szerkesztôi programjának egyik központi eleme mind korábbi lapjaiknál, mind pedig a Magyar Bazámál, a női munka volt. Az előfizetői felhívásokban külön megszólították a dolgozó nőket. A Magyar Bå̧ár több írása a nők számára rendelkezésre álló munkakörök kiszélesítése, és a nôi keresetképesség előmozdítása mellett szállt síkra, ahogy Wohl Janka nem sokkal halála előtt kijelentette egy szerkesztőségi értekezleten: „Arra kell törekednünk, hogy a nők munkájának tért és fogalmat teremtsünk!” (Hentaller 1901, 2) A 19. század utolsó évtizedeiben egyre több középosztálybeli nő kényszerült munkát vállalni azért, mert eltartó nélkül maradt (hajadon, elvált, özvegy) vagy, mert nem bizonyult elegendőnek a férj keresete. A kortársak ezt a jelenséget a középosztály anyagi gondjaival magyarázták. Így a hazai nôkérdés egyik fő témájának számított a női munka és munkaképesítés ügye, amellyel számos írás foglalkozott a 19. század végén és a 20. század elején (Sárai Szabó 2020). A Magyar Bazár az önállósodáshoz és pályaválasztáshoz kínált segítséget rovataival, tanácsadásával, cikkeivel, hirdetéseivel. Wohl Janka a gyakorlati megoldások híve volt, mivel, ahogy arra maga is többször utalt, szerkesztőként napról napra szembesült a segítséget kérő levelek halmaival. 1895. szeptember 24-i számától nyitották meg a „Mihez fogjunk?” címú pályaválasztási tanácsadó rovatot. A beérkező kérdésekre adott válaszok 
a korabeli általános felfogáshoz képest előremutatók voltak, például helyeselték Vilma azon tervét, hogy kerékpár tanfolyamot indítson vidéken vagy, hogy egy másik előfizetőjük orvosi pályára lépjen. 1899-ben nők részére jogi tanácsadó rovatot hoztak létre, amely többek között a szerződéskötésekben ígért eligazítást. Más divatlap is igyekezett hasznos segítséget nyújtani olvasóik számára, például 1893 végén, a Szabóné Nogáll Janka által szerkesztett Divat Sz̧alon „Pénzügyi útmutató” címmel új melléklettel, a Wiener Börsen-Corresponden₹ magyar kiadásával jelentkezett, amely értékpiaci híreket és tanácsokat közölt. Ugyanakkor a nők munkavállalását övező negatív sztereotípiáktól maguk az érintettek sem voltak mentesek, amit a piperetárgyak készítését és eladását tervező Iparkodó kérdése is tükröz: „Mit fognak rám mondani, ha árát szabom a munkáimnak? Nem lesz ez lealacsonyító reám nézve?” Az álnevet használó olvasó szorongásának társadalmi komponenseire mutat az erre adott válasz: „Nem írja társadalmi állását, - de sejtjük. Kegyed egy mérsékelt jövedelemmel bíró vidéki úri család leánya, nemde?” (Mihez fogjunk? 1896, 18) Az előfizetői megkeresésekből, valamint a szerkesztői üzenetekből az derül ki, hogy számos középosztálybeli, úgynevezett jó családból származó nő érdeklődött levélben jövedelmező, de nem kompromittáló munka után, hogy fenntarthassák a társadalmi állásuktól elvárt életvitelt. Ezt a Magyar Bazár mélyen elítélte, és tisztességtelennek tartotta a munkásnőkkel szemben, másfelől léhának, hogy a pénzt bálokra, ruhákra, színházra költik, a becsületes munkát pedig szégyellik. Helyettük azoknak igyekeznek jó tanáccsal szolgálni, „akik nyilt becsületességgel kiállanak a küzdők sorába és bátran szemébe néznek a léha pöffeszkedésnek az 'azt mondják'-nak, ha a körülmények megkivánják" (A mi levelezőink 1898). Továbbá Wohl Janka azt tapasztalta, hogy a hozzá fordulók többségének nincs semmiféle végzettsége, a hétköznapi életben használhatatlan, vagy felszínes tudással rendelkeznek: „mi módon lehetne minden nőt, legyen az hercegnő vagy polgárnő, ellátni a szükséges eszközökkel, miknek segélyével önállóak lehetnek" - tette fel a kérdést egyik cikkében (Wohl Janka 1890, 105). A megoldást a lányok alapos és differenciált oktatásában látta, felismerve, hogy az „önsegélyezés”, az anyagi egzisztencia megteremtése szorosan összefügg a nevelés minőségével.

A hazai divatlapok általában a nőkérdés orgánumaiként határozták meg magukat, amit bizonyos megszorításokkal lehet elfogadni, mert egyes esetekben az emancipációs szemlélettel ellentétes felfogást képviseltek. Erre jó példa a leánygimnázium eszméje, amelyet 1892-ben Vikár Béla vetett fel az Élet címú folyóiratban, a kezdeményezést ekkor azonban még nem karolta fel a kormány (Müller 2006). Az apai örökséget továbbvivő Király Kálmán vezette Budapesti Bazár így reflektált a történtekre: „A leánygymnásiumról mindeddig nem irtunk, látván, hogy mennyire kimeritik e tárgyat a napi sajtó 
és a folyóiratok és már akkor tudván, hogy e meddő téma mennyire untatja a közönséget. Annál nagyobb örömmel veszünk tudomást róla most, midőn e halva született tervet elérte sorsa.” (A leánygymnásiumról 1892,152) Pár évvel később a Divat Szalon a nők továbbtanulása és munkába állása kapcsán a következő körkérdést intézte olvasóihoz: „Ha egy fiatal lány szeretett, de anyagilag szegény férfi felesége akar lenni: mit tegyen, hogy megkönnyitse a közös gondokat? Szerezzen valami diplomát és jövedelmező hivatalt, vagy fokozza le igényeit, legyen takarékos, házias és dolgos?" A beérkező válaszokat összegezve és a vitát lezárva, a következő konklúziót vonta le a szerkesztőség: „...̈römmel tapasztaljuk, hogy olvasóink nagyobb része inkább az asszonyok igénytelensége és háziassága mellett döntött”. (Vita 1900, 24) A teljesség kedvéért nem árt utalni arra, hogy a Divat Szalon álláspontja később pozitív irányban változott. Az 1910-es évek elején már nem tartotta összeegyeztethetetlennek a nöiséget a kenyérkeresettel, többször hivatkozott elismerően a Feministák Egyesületére, sôt külföldi szüfrazsettekkel készített interjúkat (Mészáros 2020). Viszont a Magyar Bazár egyik munkatársa, Harmath Lujza, mint gyakorló gazdaasszony a falusi gazdaságokról értekezve már 1892-ben arra jut, hogy többnyire elégtelen jövedelmet termelve, csupán mellékkeresetet biztosíthatnak, a városi nők pedig még ettől a jövedelemforrástól is elesnek lakókörülményeik folytán. Megélhetési gondjaikra az egyetlen megoldást a következőben látta: „Egyetemet a nőknek!" (Harmath 1892, 62) Ez a szüfrazsettes hevületű felkiáltás - jóval Wlassics rendeletét megelőzően - a korabeli hazai sajtóközegben frissnek és üdítőnek hat.

A Wohl nôvérek által szerkesztett Magyar Bazár tehát a nők továbbtanulása mellett foglalt állást. Cikkeiben, hozzászólásaiban, rovataiban gyakorlati tudnivalókat adott közre képzési lehetőségekről, értesített nők kinevezéseiről, eredményeiről, teret adott pedagógiai fejtegetéseknek. Továbbá egyéni sikerekkel igyekezett ösztönözni olvasóit már akkor is, amikor még Magyarországon nem szerezhettek a nők felsőfokú végzettséget. Ezt szemléltetik az 1889. április 1-jei szám címlapjára került frissen diplomázott külföldi nők - Ethel Montague, a londoni egyetemen végzett angol nyelv doktora és Caroline Schultze, varsói orvos - portréi. Pár évvel késóbb, Wlassics Gyula vallás- és közoktatásügyi miniszter 1895-ös rendeletét, amely végre lehetővé tette a nők felvételét a bölcsész, orvosi és gyógyszerész egyetemi karokra, nagy sikerként könyvelte el a Magyar Bazár, és Wohl Janka a politikussal kapcsolatban úgy fogalmazott, hogy a „nők jóltevőjét tiszteljük benne" (Wohl Janka 1895, 185). Ezt követően a Magyar Bąár rendszeresen lehozta a hazai női érettségizők és diplomázók fényképpel kísért rövid életrajzait, iskolai eredményeit, ́́gy többek között az 1904-ben megalakult 
Feministák Egyesületének elnöke, ekkor, mint első beiratkozott bölcsészhallgató Glücklich Vilma tanulmányairól is időről-időre beszámolt.

Hentaller Elma kijelentése a szerkesztőség régi elköteleződéséről tanúskodik a nők oktatása iránt, amikor az immár állami engedéllyel megalakult első leánygimnáziumot méltatta: „Mi a nőnevelés, a leányiskolák érdekének szempontjából mérlegelünk és itélünk; ezt kisérjük figyelemmel, ezt dédelgetjük, igyekszünk támogatni, egy-egy homokszemmel járulva a nemzeti művelődés óriási munkájához.” (Hentaller 1897, 97) A lap ezirányú törekvései nem maradtak észrevétlenek, mert Sebestyénné Stetina Ilona, a Nemzeti Nönevelés szerkesztője Wohl Janka nekrológjában kiemelte, hogy divatlapja milyen lelkesen üdvözölte a nők egyetemi képzését, és hogy rendszeresen tudósított az ezzel és a munkaképesítéssel kapcsolatos fejleményekről (Sebestyénné Stetina 1901, 245). A női lapok közül még érdemes egyébként megemlíteni a Beksics Gusztávné és Keleti Ö. Lajos által szerkesztett Jókai Magyar Nók Lapját, amely riportjaival, tudósításaival szintén támogatta, ünnepelte az egyetemi karok nők elótti megnyitását. Visszatérve a Magyar Båárhoz, fontos azt is hozzátenni, hogy a Wohl nővérek lapja a szellemi hivatásokon túlmenően az olyan túltelített pályák, mint a tanítói vagy postahivatalnoki mellett a női keresetforrások kiszélesítése érdekében más foglalkozásokat is ajánlott olvasóinak, így az 1880-as években kibontakozó háziipar, illetve női ipar mozgalomhoz csatlakozva, azt a női önállósodás egy további alternatívájaként mutatta fel elsősorban a vidéken élőkre gondolva, akik a lap előfizetői bázisát alkották. A szerkesztőség rájuk irányuló figyelmét, érdekeiknek képviseletét illusztrálja a következő példa is: az 1892-es évfolyam első számában a Magyar Tisztviselők Országos Egyesülete által kezdeményezett, budapesti hatókörű „női munkát értékesitő egylet” megalakulásáról szóló felhívást közzétéve, arra kérték az új szervezetet, hogy ne zárja ki a vidéki tagokat sem, mert lakóhelyükön sokkal kevesebb kereseti lehetőség áll a rendelkezésükre, így még inkább rászorulnak a segítségre és közvetítésre ezen a téren.

Az önállósodás igénye nemcsak a munka vagy a tanulás, hanem a modern testkultúra témakörében is jelentkezett a Magyar Baحár hasábjain: 1885-től külön rovat indult „Nők a sport terén” címmel, illetve reprodukciók, ismeretterjesztô írások népszerüsítették a testedzés olyan formáit, mint a gimnasztika, a tenisz, a vívás vagy a biciklizés. Ez korántsem számított magától értetődőnek vagy szokványosnak a korabeli Magyarországon: „A nők a 19. század végéig csak szórványosan folytattak önmagáért való sporttevékenységet. A mértékletes testedzés csak a testi-lelki panaszokat kúráló orvosi javallatban merülhetett fel. A kor embere amúgy sem erőfeszitést és verejtékezést akart látni az (úri)nőktől” (Szécsi - Géra 2015, 295). A lap viszonylag hamar és a hazai sajtóban úttörő módon, az 1880-as 
évek végétôl kezdve propagálta női olvasói számára a kerékpározást, miközben a közgondolkodásban összekapcsolódva az „Új Nő” alakjával, a 19. századi emancipációs folyamatok jelképeként borzolta a kedélyeket, és a társadalmi rendet fenyegető jelenségként értelmezték (Fuchs-Thompson 2005, Kéri 2020). A Képes Családi Lapok mellékletének, a Hölgyek Lapjának Pipifax álnevú munkatársa szerint a bicikli miatt elhanyagolják a nők családjukat és a háztartást, mivel reggel és alkonyatkor a legkellemesebb nyeregbe pattanni, így nem tudják elvégezni az azokhoz a napszakokhoz kötődő olyan teendőiket, mint a reggeli és vacsora készítés, vagy a gyerekek fürdetése, iskolába küldése, lefektetése (Pipifax 1897). A vérmérséklettől függően szorongó, illetve vehemens kritikákkal szemben Wohl Janka, bár saját bevallása szerint sosem próbálta ki, a szerkesztőségbe érkező több száz hasonló kérdésre, miszerint illik-e biciklizni nőnek, habozás nélkül ezt válaszolta: „Illik, hát, felelem teljes meggyőződéssel...” (Wohl Janka 1896, 114) A kerékpárról címú, népszerűsítő cikkére kapott felháborodott levél feladójának, M. F. monogramú tanácsosnak pedig nyitottságot és utazást javasolt, hogy minél több pozitív külföldi példát ismerjen meg: „Ma már nemcsak azt kérdi a nő: minek van sziv és a szivben szerelem? hanem azt is kérdi: minek van tudomány, mûvészet, a szellem végtelen birodalma, minek van lelkem és eszem, ha ezekből kizárva legyek és tisztán a kávétratschnak és rántásfőzésnek szenteljem életemet?” (Wohl Janka 1897).

\section{Összefoglalás}

Bár hasábjain a választójog ritkán tűnt fel, a Magyar Bazár együttmúködött a hazai nőmozgalmak szervezeteivel, képviselőivel, továbbá az emancipáció több szintjéhez kapcsolódva, teret adott a továbbtanulásban, tudományban és művészetekben való részvétel, a munkaképesítés és -vállalás nőket érintő felvetéseinek, problémáinak, megoldási alternatíváinak, így az álláskeresésnek, a házi- és nőipari mozgalomnak, a sportolásnak, a közép- és felsőoktatásnak. Más 19. század végi magyar divatlap esetében szintén megfigyelhető, hogy változó mértékben és bizonyos megszorításokkal ugyan, de ösztönözték a nők önszerveződését, egyéni és kollektív aktivitását, anyagi és szellemi függetlenedését. A korabeli, családi feladatokhoz kötődő középosztálybeli normák megerősítése mellett, hasábjaikon lehetőséget kínáltak a társadalmi nemi elvárások megvitatására vagy éppen felülírására. Szerkesztésük, tartalmuk, múködésük vizsgálata a 19. századi magyar nő́mozgalmak egymásra épülő hálózata felé vezetnek, ami sok szállal kapcsolódott a 20. század elejének feminista törekvéseihez. Mindebben közvetítő szerepet játszottak a divatlapok: közvetítettek nőképek, eszmék, mozgalmak, kortársak és nemzedékek között. 


\section{Felhasznált kéziratos forrás}

Wohl Janka levele Szilágyi Sándornak, 1. sz., 1870. november 3., 1. oldal, OSzK Kézirattár, Levelestár, Fond IX/725.

\section{Felhasznált irodalom}

„A leánygymnásiumról.” 1892. Budapesti Baqáa 33 (19): 152.

„A mi levelezőink.” 1898. Magyar Bazár 33 (1): boríték.

Acsády Judit. 1996. „Lovagiasságtól a vádaskodásig: Képek a magyarországi antifeminizmus tablójáról." Educatio 5 (3): 454-466.

Bajomi-Lázár Péter. 2015. „Rendhagyó szerkesztői jegyzet: A kommunikációés médiatudomány magyarországi helyzetéről." Médiakutató 16 (1): 58.

Ballagi Mór. 1873. „Egy nevezetes könyvről.” A Nók Munkaköre 1 (1): 1-2.

Ballaster, Ros, Margaret Beetham, Elizabeth Frazer and Sandra Hebron (ed.). 1991. Women's Worlds: Ideology, Femininity and the Woman's Magazine. Basingstoke and London: Macmillan.

Beauvoir, Simone de. 1969 [1949]. A második nem. Ford. Görög Lívia és Somló Vera. Budapest: Gondolat.

Beetham, Margaret. 1996. A Magazine of Her Own? Domesticity and Desire in the Woman's Magazine, 1800-1914. London and New York: Routledge.

Székely Huszár [Benedek Elek]. 1891. A hétről. Orsqág-Világ 12 (39 (1891): 646.

Bozsoki Petra. 2018. „Kánya Emília diszkurzív közege: A Családi Kör női szereprepertoárja és politikai nyelve." Irodalomtörténeti Kö̊lemények 122 (5): 580-602.

Brevik-Zender, Heidi. 2015. Fashioning Spaces: Mode and Modernity in LateNineteenth-Century Paris. Toronto, Buffalo, London: University of Toronto Press.

Breward, Christopher and Caroline Evans (ed.). 2005. Fashion and Modernity. Oxford and New York: Berg.

Buzinkay Géza. 1985. „Közmúvelődési sajtó 1867-1875.” In Kosáry Domokos és Németh G. Béla (szerk.). A magyar sajtó története II/2, 1867-1892. Budapest: Akadémiai, 209-247. 
Buzinkay Géza és Kókay György. 2005. A magyar sajtó története I. A keezdetektól a fordulat évéig. Budapest: Ráció.

Carter, Cynthia and Linda Steiner. 2004. "Mapping the Contested Terrain of Media and Gender Research." In Cynthia Carter and Linda Steiner (ed.). Critical Readings: Media and Gender. Maidenhead: Open UP, 1135.

Conboy, Martin and John Steel. 2015. „Introduction: British media and mediations of the past." In Martin Conboy and John Steel (ed.). The Routledge Companion to British Media History. Abingdon and New York: Routledge, 1-5.

Curran 2008 - Curran, James. 2008. „Communication and History.” In Barbie Zelizer (ed.). Explorations in Communication and History. London and New York: Routledge, 46-59.

Császi Lajos. 2008. „Médiakutatás a kulturális fordulat után.” Médiakutató 9 (3): 93-108.

Dezsényi Béla és Nemes György. 1954. A magyar sajtó 250 éve. I. kötet. Budapest: Múvelt Nép.

Egy megkeseritett hajadon. 1896. „Mikor lesz a nő 'vén leány' (A 'Magyar Bazár' szerkesztőjéhez).” Magyar Bazár 31 (45): oldalszám nélkül; A kérdésre beérkezett válaszok. 1896. Magyar Bazár 31 (47): oldalszám nélkül

Fabó Edit. 2007. A magyar dualiz̧mus kori karikatúrák és paródiák: A nökkel kapcsolatos társadalmi sztereotípiák változása az élclapok tükrében. Doktori disszertáció. Budapest: ELTE BTK.

Ferguson, Marjorie. 1983. Forever Feminine: Women's Magazines and the Cult of Femininity. London: Heinemann.

Fővárosi Lapok-hirdetés. 1892. Magyar Bąár 27 (7): boríték.

Friedan, Betty. 1963. The Feminine Mystique. New York: W. W. Norton and Co.

Fuchs, Rachel G. and Victoria E. Thompson. 2005. Women in NineteenthCentury Europe. Basingstoke and New York: Palgrave Macmillan.

Gyáni Gábor. 2006. „Sajtótörténet a társadalomtörténész szempontjából.” Médiakutató 7 (1): 57-64.

Harmath Lujza. 1892. „Néhány észrevétel a komoly szóhoz.” Magyar Bazár 27 (8): 62 .

Hentaller Elma. 1896. „A legújabb nőalakok.” Magyar Bazár 31 (44): 173. 
Hentaller Elma. 1897. „Az első leánygymnasium.” Magyar Båár 32 (26): 9798.

Hentaller Elma. 1901. „Wohl Janka mint szerkesztő.” Magyar Baðá́r 36 (21): 2.

Hölgyfutár. 1862.13 (67): 532.

Kádár Judit. 2002. „’Otthonod az uradé’: Három 20. századi magyar képes hetilap nőképe." Médiakutató 3 (9): 78-94.

Kéri Katalin. 2008. Hölgyek napernyövel: Nók a dualižmus kori Magyarországon 1867-1914. Pécs: Pro Pannonia.

Kéri Katalin. 2020. „Tornázó lányok, sportoló nők a 19-20. század fordulóján Magyarországon." Per Aspera Ad Astra 7 (2): 31-53.

Lipovetsky, Gilles. 1987. L'Empire de l'éphémère. La mode et son destin dans les sociétés modernes. Paris: Gallimard.

Lipták Dorottya. 2002. Újságok és újságolvasók Ferenc József korában (Bécs-BudapestPrága). Budapest: L'Harmattan.

Lipták Dorottya. 2011. „A modernkori könyv- és sajtótörténeti kutatások állapotáról: Paradigmaváltás - problémafeltárás - alapelvek programok - feladatok." Magyar Tudomány 172 (9): 1121-1131.

Lukács Anikó. 2016. „Jámbor Endre és a Férfidivat-közlöny: Szabászati szaklapok az 1860-as években.” In F. Dózsa Katalin, Szatmári Judit Anna és Vér, Eszter Virág (szerk.). Divat, egyén, társadalom: $A$ divattörténeti tudományos konferencia tanulmánykötete. Budapest: ELTE Eötvös, 111-127.

Mahotka Jenő. 1934. Szépirodalmi folyóirataink története az abszolutizmus korában. Budapest.

Mészáros Zsolt. 2017. „Női hálózatok és a 19. századi divatlapok: A Magyar Bazár és olvasóközönsége.” Magyar Könyvsžemle 133 (3): 297-313.

Mészáros Zsolt. 2020. „Politikák - divatok: Történelemről, öltözködésről, feminizmusról és irodalomról a Budapesti Bazár és a Divat Szalon hasábjain (1918-1921)." In Kappanyos András, Sarankó Márta és Szénási Zoltán (szerk.). Üdvözlet a gyózốnek: Tanulmányok 1918 mikrotörténelméról. Budapest: Bölcsészettudományi Kutatóközpont, 383-397.

„Mihez fogjunk?” 1896. Magyar Bazár 31 (4): 18 
Miklóssy János. 1976. „Irodalmi folyóirataink a Bach-korszakban (1849_ 1859)." In Az Országos Széchényi Könyvtár Évkönyve 1973. Budapest, 233-290.

Miklóssy János. 1985. „Az abszolutizmus első szakaszának sajtója 1849-1859, VIII. Irodalmi lapok." In Kosáry Domokos és Németh G. Béla (szerk.). A magyar sajtó története II/1, 1848-1867. Budapest: Akadémiai, $417-442$.

Müller Ildikó. 2006. „Kísérlet a nők középiskolai képzésének megszervezésére: a budapesti állami felsőbb leányiskola és leánygimnázium.” In Kövér György (szerk.). Zsombékok. Középosżtályok és iskoláztatás Magyarországon a 19. squáaad elejétól a 20. század közepéig. Budapest: Századvég, 673-711.

Nagydiósi Gézáné. 1958. „Magyarországi női lapok a XIX. század végéig.” In Az. Országos Széchényi Könyvtár Évkeönyve 1957. Budapest, 193-229.

Nelson Best, Kate. 2017. The History of Fashion Journalism. London and New York: Bloomsbury.

Nerone, John. 2006. „The Future of Communication History.” Critical Studies in Media Communication 23 (3): 254-262.

Ország-Világ. 1894. 15 (18): 293

Pintér Györgyi. 2013. „Sajtókutatás - divatlapkutatás. A reformkori divatlaptörténet-írás esélyei." Médiakutató 14 (4): 37-44.

Pipifax. 1897. „Bicikli és - főzőkanál!” Képes Családi Lapok Hölgyek Lapja 19 (31): oldalszám nélkül

Rákosi Jenő. 1926. Emlékezések I. Budapest: Franklin.

Sárai Szabó Katalin. 2014. „Normakövető női emancipáció: A konzervatív nőmozgalom Magyarországon a 19. század végén, 20. század elején.” Replika 85-86: 85-106.

Sárai Szabó Katalin. 2020. „’Mellékize van a kenyerünknek.’: A női munkavállalásról szóló diskurzus a 19. század második felében és a 20. század elején.” In Török Zsuzsa (szerk.). Nök, idôszaki kiadványok és nyomtatott nyilvánosság 1820-1920. Budapest: reciti, 299-333.

Sebestyénné Stetina Ilona. „Wohl Janka.” Nemzeti Nönevelés 22 (6): 242-245.

Sipos, Balázs. 2003. „Unter Disziplinen. Historische Medien- und Kommunikationsforschung in Ungarn." Medien \& Zeit 18 (3): 8-22. 
Szajbély Mihály. 2005. „A médiatörténet és a sajtótörténet viszonyáról.” Médiakutató 6 (1): 71-79.

Széchenyi Ágnes. 2004. „A huszadik század hiányzó magyar sajtótörténete adósságlista és javaslat." Magyar Tudomány 111 (10): 1150-1163.

Szécsi Noémi és Géra Eleonóra. 2015. A budapesti úrinö magánélete (1860-1914). Budapest: Európa.

T. Erdélyi Ilona. 1970. Irodalom és közöönség a reformkorban: Regéló Pesti Divatlap. Budapest: Akadémiai.

Tamás Anna. 1970. Az Életképeke (1846-1848). Budapest: Akadémiai.

Tamás Ernő. 1939. „A Hölgyfutár és a divatlapok a magyar irodalomban.” In Légrády Testvérek. Naptára 1940. Budapest: Légrády Testvérek, 194-198.

Török Zsuzsa. 2020. „Bevezetô.” In Török Zsuzsa (szerk.). Nók, idősqaki kiadványok és nyomtatott nyilvánosság 1820-1920. Budapest: reciti, 7-10.

Turák János. 1961. „A divatlapok szerepe Magyarországon a XIX. század második felének irodalmi életében.” In A Szegedi Pedagógiai Föiskola Évkönyve 1961. Első rész. Szeged, 63-71.

„Vita." 1900. Divat Szalon 13 (16): 24.

Wilson, Elizabeth. 1985. Adorned in Dreams: Fashion and Modernity. Berkeley and London: Virago and University of California Press.

Wohl Janka. 1871. „Hagyjatok dolgozni.” A Divat 6 (3): 18.

Wohl Janka. 1875. „A 'régi jó idők' kiváló hölgyei.” Fóvárosi Lapok 12 (98): 438-439, (100): 446-447, (105): 470-471.

Egy nagyvilági hölgy [Wohl Janka]. 1890. „Alaposan kell tudni legalább egy dolgot." Magyar Bazár 25 (14): 105.

Wohl Janka. 1895. „Wlassics Gyula.” Magyar Bazár 30 (46): 185.

Wohl Janka. 1896. „A kerékpározás Angliában.” Magyar Bąár 31 (28): 114.

Wohl Janka. 1897a. „A kerékpárról.” Magyar Bazár 32 (24): 94-96, (26): 103 104.

Egy sokat utazott nem bicziklista nő [Wohl Janka]. 1897b. „Válasz M. F. tanácsos ur levelére, melylyel 'A kerékpárról' irt czikkemre vonatkozólag megtisztelt.” Magyar Bazár 32 (29): oldalszám nélkül

Wohl Stefánia. 1866. „Izidóra: Gróf Bethlen Miklósné.” A Divat 1 (22): 257. 
W. S. [Wohl Stefánia]. 1871. „Gróf Brunswick Teréz.” A Divat 6 (21): 162 163, (22): 170, (23): 177.

Wohl Stefánia. 1872. „Olvasóinkhoz!” A Nők Munkaköre mutatványszám (november 20.): 1.

Wolf, Naomi. 1999 [1990]. A sæépség kultusza. Ford. Follárdt Natália. Debrecen: Csokonai.

Z. Karvalics László. 2014. „Horizontokat tágító és civilizáló erő: Az információtörténeti fordulat irányairól és esélyeiről a sajtótörténetírásban." Médiakutató 15 (2): 7-15.

Zelizer, Barbie. 2008. „When disciplines engage.” In Barbie Zelizer (ed.). Explorations in Communication and History. London and New York: Routledge, 1-12. 